\title{
EFFECT OF RESIDENCE TIME ON PRODUCTS YIELD AND CHARACTERISTICS OF SHALE OIL AND GASES PRODUCED BY LOW-TEMPERATURE RETORTING OF DACHENGZI OIL SHALE
}

\author{
SHA WANG ${ }^{(a)}$, XIUMIN JIANG $^{(\text {a)* }}$, XIANGXIN HAN ${ }^{(a)}$, \\ JIANHUI TONG ${ }^{(\mathrm{a}, \mathrm{b})}$
}

(a) Institute of Thermal Energy Engineering, School of Mechanical Engineering, Shanghai Jiao Tong University, Shanghai 200240, PR China

(b) School of Materials Science and Engineering, Jingdezhen Ceramic Institute, Jingdezhen 333001, PR China

\begin{abstract}
Oil shale samples from Dachengzi mine located in Huadian city, Jilin province, China, were retorted in a stainless-steel cylindrical retort under argon atmosphere to determine the influence of residence time on the products yield and characteristics of shale oil and gases. It was found that the liquid yield increased with increasing residence time from 6 to $40 \mathrm{~min}$, and then leveled off as the residence time further increased. The gases yield also increased with increasing residence time, while the shale char yield decreased. When prolonging the residence time from 6 to $60 \mathrm{~min}$, the atomic $H / C$ ratio of the derived shale oils decreased from 2.007 to 1.768 , both the oxygen and sulfur content also decreased, while the nitrogen content slightly increased. It was also noticed that high boiling point oils were produced in the initial stage of the retorting process and low boiling point oils in its later stages. The shale oil obtained in $20 \mathrm{~min}$ had the lowest quantity of heavy fractions, $52.8 \mathrm{wt} \%$, whilst the shale oils produced in 40 and 60 min showed similar boiling point distribution. The produced shale oils had similar atomic $H / C$ ratio and lower heavy oil content compared to crude oils, and could be classified as sweet and high-nitrogen oil in terms of the classification method of crude oil. Extending the residence time decreased the aliphatics content and increased the aromatics content of the produced shale oil. When the residence time was $40 \mathrm{~min}$, the derived oil contained the lowest amount of asphaltenes and the highest amount of non-hydrocarbons. Moreover, the produced gases contained maximum concentrations of $C_{1}-C_{4}$ gases (except propane) and had the lowest ethene/ethane ratio and the highest propene/propane and butene/butane ratios. The alkene/alkane gases ratio increased from 0.27 to 0.65 with increasing residence time from 6 to $60 \mathrm{~min}$,
\end{abstract}

\footnotetext{
* Corresponding author: e-mail xiuminjiang@sjtu.edu.cn
} 
which reflected the increasing secondary cracking reactions during a longer residence time.

Keywords: oil shale, retorting, residence time, gases, shale oil, yield, characteristics.

\section{Introduction}

As the world's primary source of energy and chemicals, oil remains a dominant fuel for the many years to come, having accounted for $33.6 \%$ of global energy consumption in 2010 with the current demand of about 87.4 million barrels per day with a projection to increase to 105.5 million barrels per day by $2030[1,2]$. The current global excessive dependence on oil may cause economic problems and instability of energy security in the high price oil period [3]. In order to keep the balance between energy supply and demand, some countries have been encouraged to explore unconventional oil sources, such as oil shale, oil sands and coal [4].

Oil shale, a fine-grained sedimentary rock containing significant amounts of kerogen, is widely distributed throughout the world. There are about 600 known oil shale deposits containing estimated 3 trillion barrels of shale oil, therefore oil shale represents a valuable potential alternative to crude oil [5]. The kerogen in oil shale can be converted by retorting into shale oil as an alternative to conventional oil $[3,6]$. For the maximum and efficient extraction of shale oil from oil shales, the effect of reaction conditions, such as heating rate, retorting temperature, residence time, particle size, etc., has been investigated to determine optimal reaction parameters that would allow producing high quality shale oil [3,7-18]. Up to now, most studies have focused on the pyrolysis kinetics of oil shale or the products yield as a function of operating variables, especially heating rate and retorting temperature, which are most studied variables affecting thermal decomposition of kerogen and as a consequence pyrolysis products and secondary reactions $[3,4,7-15]$. Such reactions are also affected by residence time. However, there are few studies in the literature about the influence of residence time on pyrolysis products $[13,14,19,20]$. At the same time, the dependence of the properties of shale oil and gases on pyrolysis conditions has rarely been reported.

In this paper, oil shale samples from Dachengzi mine located in Huadian city of China have been retorted in a stainless-steel cylindrical retort. The effect of residence time on the products yield and properties of shale oil and gases has been investigated. Residence time here refers to the length of time (in minutes) during which an experiment is run at the final retorting temperature. The produced shale oils have been subjected to elemental analysis, high temperature simulated distillation and chemical class fractionation (aliphatics, aromatics, non-hydrocarbons, and asphaltenes). The hydrocarbon gases up to $\mathrm{C}_{4}$ in the gases have been analyzed. Such information is needed 
not only to understand the process reaction mechanisms, but also to optimize the process and enhance the shale oil yield and quality.

\section{Experimental}

\subsection{Oil shale samples}

The oil shale samples investigated in this paper were obtained from Dachengzi mine located in Huadian city, China. Table 1 shows the general characteristics of the samples. The original oil shale samples were sampled, crushed, ground and sieved to a grain size of $0-3 \mathrm{~mm}$, considering the National Standards of China (GB 474-1996). All samples were dried in an oven at $105{ }^{\circ} \mathrm{C}$ for a period of $10-12$ hours, and then stored in a desiccator to avoid any adsorption of water or loss of volatiles.

Table 1. Analysis of Dachengzi oil shale

\begin{tabular}{|l|c|c|c|c|c|}
\hline \multicolumn{2}{|c|}{ Proximate analysis } & \multicolumn{2}{c|}{$\begin{array}{c}\text { Ultimate analysis, } \\
\text { wt } \%, \mathrm{~d}\end{array}$} & \multicolumn{2}{c|}{$\begin{array}{c}\text { Retorting assay data } \\
\mathrm{wt} \%,\end{array}$} \\
\hline Moisture, wt $\%$, ar & 11.54 & $\mathrm{C}$ & 30.90 & Shale oil & 19.20 \\
Volatile matter, wt $\%$, ar & 36.21 & $\mathrm{H}$ & 4.058 & Shale char & 63.77 \\
Ash, wt $\%$, ar & 48.24 & $\mathrm{O}^{\mathrm{a}}$ & 8.919 & Water & 11.88 \\
Fixed carbon, wt $\%$, ar & 4.01 & $\mathrm{~N}$ & 0.64 & Gases & 5.15 \\
Low heating value, $\mathrm{kJ} / \mathrm{kg}$, ar & 11076.07 & $\mathrm{~S}$ & 0.95 & & \\
\hline
\end{tabular}

a Calclulated by difference.

${ }^{b}$ Under the National Standard of China (SH/T 0508-92).

\subsection{Retorting system}

All experiments were conducted in a stainless-steel cylindrical retort $(70 \mathrm{~mm}$ i.d., $100 \mathrm{~mm}$ height). 50 grams of dried oil shale samples was placed inside the retort before each test and electrically heated from room temperature to a final retorting temperature of $430{ }^{\circ} \mathrm{C}$ at a fixed heating rate of $12{ }^{\circ} \mathrm{C} \mathrm{min}{ }^{-1}$ by using argon as the purge gas. The residence time at $430{ }^{\circ} \mathrm{C}$ was $6,20,40$ and $60 \mathrm{~min}$, respectively. Oven temperature controlled and monitored by a digital temperature controller was indicated by an oven thermocouple (see Fig. 1), which was situated between the external body of the retort and the inner side of the ceramic cylinder. Heating rate was controlled through changing the power supply voltage input to the retort heater. Argon sweep gas at the rate of $0.3 \mathrm{~L} \mathrm{~min}^{-1}$ was introduced from the top of the retort in an $8 \mathrm{~mm}$ pipe for preheating while passing downward to the bottom of the retort and then was allowed to disperse to sweep the generated products toward the retort side outlet to minimize secondary reactions [12]. The liquid products were trapped in a series of cold traps which were immerged in low-temperature troughs $\left(\mathrm{ab} \quad{ }^{\circ} \mathrm{C}\right)$ filled with the mixture of ice and water, while the gases were directed through the U-tube and mixed with argon at the rate of 


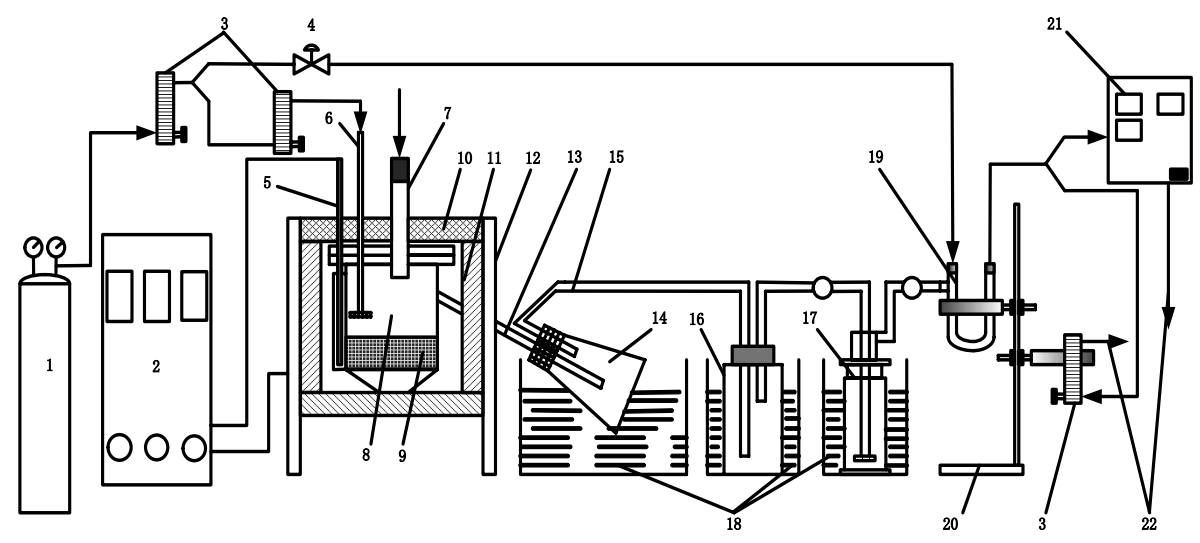

Fig. 1. Schematic diagram of the experimental retorting system of oil shales.

1 - argon cylinder, 2 - automatic temperature controller, 3 - flowmeter, 4 - flow control valve, 5 - thermocouple, 6 - gas inlet, 7 - sample inlet, 8 - retort reactor, 9 - oil shale, 10 - insulation, 11 - electric heater, 12 - steel stand, 13 - copper tube, 14 - conical flask, 15 - silicone tube, 16 - wide-mouthed bottle, 17 - gas washing bottle, 18 - water/ice condenser, 19 - U-tube, 20 - stand, 21 - gas analyzer, 22 - vent.

2.7 $\mathrm{L} \mathrm{min}^{-1}$. Part of the gas mixture was sampled into the online gas analyzer for analyzing component concentrations as a function of time and then vented from the gas analyzer outlet into the atmosphere. The rest of the gas mixture was also vented into the atmosphere via a flowmeter which kept the volume flow of gases into the analyzer constant $\left(3 \mathrm{~L} \mathrm{~min}^{-1}\right)$. After the retorting temperature was kept constant for a specified period of residence time, the experiment ceased. The reactor was fast removed from the heating furnace and then placed in a large low-temperature trough $\left(\mathrm{ab} 0{ }^{\circ} \mathrm{C}\right)$ filled with the mixture of ice and water to be cooled. Shale char and the mixture of shale oil and water were collected and weighed, respectively. The gases yield was determined by overall material balance. The derived liquid product consisted of an aqueous phase and an oil phase. The oil was separated from the aqueous phase by centrifuging and decanting, and removing the aqueous phase by pipette for elemental analysis, high temperature simulated distillation and chemical class fractionation [21-23]. In order to assess the reproducibility, each retorting test was performed twice under identical conditions.

\subsection{Gas analysis}

The gas mixture sample emitted from the U-tube was continuously directed to an on-line Fourier transform infrared (FTIR) gas analyzer (GASMET DX-4000; Gasmet Technologies, USA; $8 \mathrm{~cm}^{-1}$ resolution, high path gas cell of length $9.8 \mathrm{~m}$ ). The gas analyzer was composed of two units: the sampling unit for gases sampling and cleaning, and the measuring unit for continuous analysis with an FTIR analyzer. Before each test, the background spectrum 
was recorded when argon flowed through the sample cell at the rate of $1.2 \mathrm{~L} \mathrm{~min}^{-1}$. Then the sample was continuously measured by the analyzer at 1.046 bar and $180^{\circ} \mathrm{C}$ and the sample spectra were recorded. The infra-red spectra obtained were processed by Calcmet Software 2005 which was connected to the analyzer via RS232. The FTIR spectra were recorded for the following components: $\mathrm{NO}, \mathrm{NO}_{2}, \mathrm{~N}_{2} \mathrm{O}, \mathrm{NH}_{3}, \mathrm{CH}_{4}, \mathrm{C}_{2} \mathrm{H}_{6}, \mathrm{C}_{3} \mathrm{H}_{8}, \mathrm{C}_{4} \mathrm{H}_{10}$, $\mathrm{C}_{2} \mathrm{H}_{4}, \mathrm{C}_{3} \mathrm{H}_{6}, \mathrm{C}_{4} \mathrm{H}_{8}, \mathrm{C}_{2} \mathrm{H}_{2}, \mathrm{SO}_{2}, \mathrm{CS}_{2}, \mathrm{CO}, \mathrm{CO}_{2}$, and $\mathrm{H}_{2} \mathrm{O}$. This paper mainly investigated $\mathrm{C}_{1}-\mathrm{C}_{4}$ hydrocarbon gases.

\subsection{Oil analysis}

\subsubsection{Elemental analysis}

The shale oil samples were analyzed for CHNO using a Vario EL cube CHNOS elemental analyzer (ELEMENTAR, Germany) and for total sulfur content by a Jena EA3100 NS analyzer (Carl Zeiss, Germany).

\subsubsection{High temperature simulated distillation}

The boiling point distribution of liquid products was obtained by high temperature simulated distillation (HTSD), using an ASTM method HT 750 (AC Analytical Controls Method; Analytical Controls, Inc., USA). This HTSD analysis was performed with an Agilent $6890 \mathrm{~N}$ gas chromatograph (Agilent Technologies, Inc., USA) equipped with an auto sampler and an automatic injector. The carrier gas was helium $(99.999 \%$ purity) with a constant flow rate of $3 \mathrm{~mL} \mathrm{~min}^{-1}$. The GC contained a $5 \mathrm{~m} \times 0.53 \mu \mathrm{m} \times 0.09 \mu \mathrm{m}$ capillary column (AC SIMDIS HT 750; Analytical Controls, Inc., USA) with a cool on-column injector. Temperature programming for the column was $10{ }^{\circ} \mathrm{C} \mathrm{min}$ m $^{-1}$ from $40{ }^{\circ} \mathrm{C}$ to $430{ }^{\circ} \mathrm{C}$ (maintained for $5 \mathrm{~min}$ ). The on-column injector was programmed from $100{ }^{\circ} \mathrm{C}$ to $430{ }^{\circ} \mathrm{C}$ (run time $22 \mathrm{~min}$ ) with a temperature gradient of $15{ }^{\circ} \mathrm{C} \mathrm{min}$. The flame ionization detector (FID) was maintained at $430{ }^{\circ} \mathrm{C}$.

\subsubsection{Chemical class fractionation}

The chemical class fractionation (aliphatics, aromatics, non-hydrocarbons, and asphaltenes) of shale oil samples was carried out using the Chinese Petroleum Industrial Standard SY/T 5119-2008. A total of $30 \mathrm{~mL}$ of hexane was added to $50 \mathrm{~mL}$ of shale oil sample. The mixture sat for $12 \mathrm{~h}$ and then was filtered through a funnel covered with cotton wool. The hexane-insoluble matter on the cotton wool was washed with hexane until the filtrate was clear. The hexane-insoluble asphaltenes remaining on the cotton wool were dissolved and washed by dichloromethane. The hexane-soluble matter collected was subjected to aliphatic, aromatic and non-hydrocarbon fractionation. A glass column ( $8 \mathrm{~mm}$ inner diameter $\times 300 \mathrm{~mm}$ length $)$ was packed with $3 \mathrm{~g}$ of silica gel $\left(80-100\right.$ mesh, activated at $150{ }^{\circ} \mathrm{C}$ for $\left.8 \mathrm{~h}\right)$ and $2 \mathrm{~g}$ of neutral alumina (100-200 mesh, activated at $400{ }^{\circ} \mathrm{C}$ for $\left.4 \mathrm{~h}\right)$. Cotton 
wool was inserted at the bottom of the column. After the hexane-soluble matter was poured through the packed column, $25 \mathrm{~mL}$ of hexane was added to elute the aliphatic fraction. The aromatic fraction was obtained by eluting the column with a $15 \mathrm{~mL}$ mixture of hexane/dichloromethane $(1: 1, \mathrm{v} / \mathrm{v})$. The non-hydrocarbon fraction was obtained by eluting the column with $10 \mathrm{~mL}$ of ethanol, followed by $15 \mathrm{~mL}$ of chloroform.

\section{Results and discussion}

\subsection{Products yield}

Figure 2 presents liquid, gases, and shale char yields as a function of residence time. It can be seen that the liquid yield varies from $13.67 \mathrm{wt} \%$ to $24.86 \mathrm{wt} \%$ as the residence time increases from 6 to $60 \mathrm{~min}$, and the yield obviously increases by $7.836 \mathrm{wt} \%$ from 6 to $20 \mathrm{~min}$, by $3.288 \mathrm{wt} \%$ from 20 to $40 \mathrm{~min}$ and only by $0.066 \mathrm{wt} \%$ from 40 to $60 \mathrm{~min}$, showing that prolonging the residence time at low retorting temperature has a limited effect on the increase in the liquid yield. The experiment showed that liquid droplets nearly disappeared and gases were continuously generated in $60 \mathrm{~min}$. A similar effect of residence time on the liquid yield was found by Han et al. $[13,14]$ who showed that more residual organic matters had cracked to gases during the residence time of $60 \mathrm{~min}$. In this paper, the gases yield increases with increasing residence time, and reaches $6.16 \mathrm{wt} \%$ in $60 \mathrm{~min}$. In addition, it can be observed that there was no significant change in shale char yield as the residence time extended from 40 to $60 \mathrm{~min}(69.9 \mathrm{wt} \%$ in $40 \mathrm{~min}$ and $68.98 \mathrm{wt} \%$ in $60 \mathrm{~min}$, respectively). This indicates that the complete decomposition of the sample has been achieved and the residence time

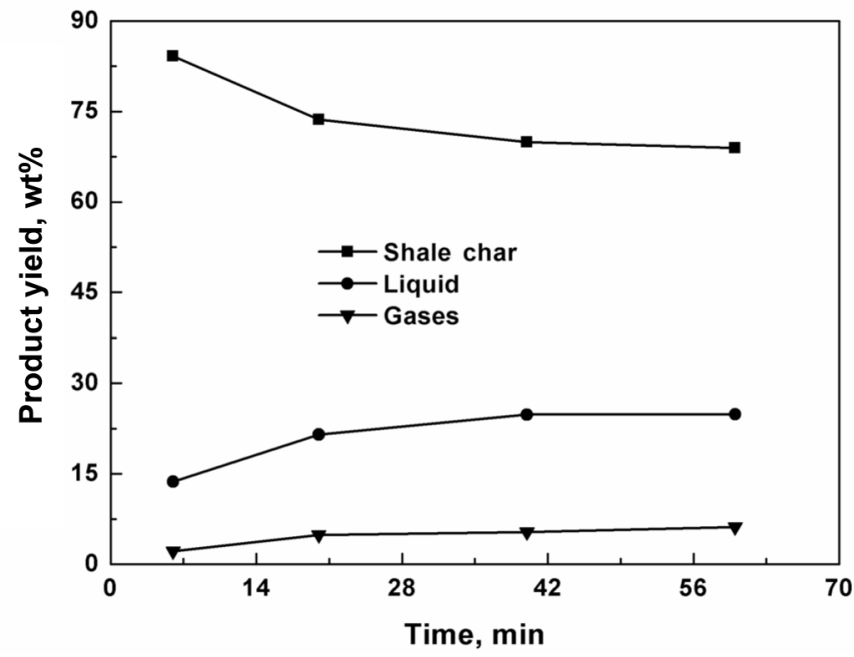

Fig. 2. Influence of residence time on the yield of products derived by retorting Dachengzi oil shale. 
of $40 \mathrm{~min}$ is long enough for the retorting of kerogen. As reported by some authors, heat transfer in kerogen is limited and the pyrolysis process has not enough time to proceed during a short residence time, whereas for the process to proceed during a longer residence time, higher input heat is needed [24-26]. So, to ensure high shale oil yield and save on process cost, the residence time of $40 \mathrm{~min}$ is optimal for this stainless-steel cylindrical retort at the retorting temperature of $430{ }^{\circ} \mathrm{C}$.

\subsection{Oil analysis}

3.2.1. Elemental analysis

Figure 3 shows the influence of residence time on the atomic $\mathrm{H} / \mathrm{C}$ ratio, as well as oxygen, sulfur and nitrogen contents of the derived shale oil. It can

(a) $\mathrm{H} / \mathrm{C}$ atomic ratio

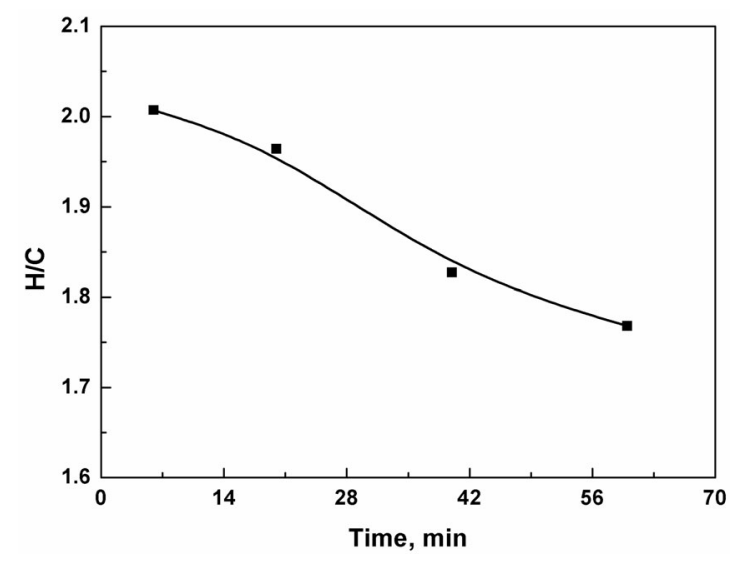

(b) ONS content

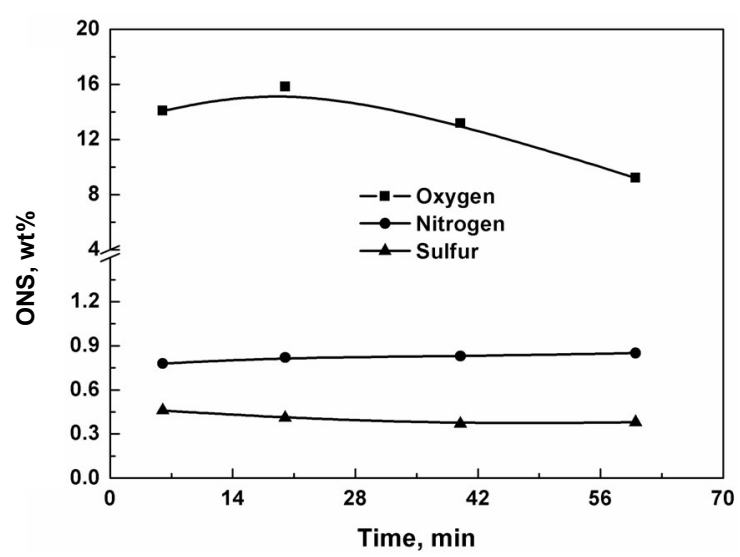

Fig. 3. Influence of residence time on (a) the $\mathrm{H} / \mathrm{C}$ atomic ratio and (b) ONS content of shale oils derived by retorting Dachengzi oil shale. 
be seen in Figure 3a that the atomic $\mathrm{H} / \mathrm{C}$ ratio decreases from 2.007 in 6 min to 1.827 in $40 \mathrm{~min}$, which may be attributed to the obtained shale oil comprising considerable amounts of aromatic compounds. Some researchers also reported that the decrease of the atomic $\mathrm{H} / \mathrm{C}$ ratio may indicate the produced oil more aromatic in nature [17]. Simultaneously, it is found that the atomic $\mathrm{H} / \mathrm{C}$ ratio decreases slightly from 1.827 to 1.768 as the residence time increases from 40 to $60 \mathrm{~min}$, which suggests small changes in the characteristics of shale oil after $40 \mathrm{~min}$. In addition, Figure $3 \mathrm{~b}$ shows that the nitrogen content increases from 0.78 to $0.85 \mathrm{wt} \%$ with increasing residence time from 6 to $60 \mathrm{~min}$, while both the oxygen and sulfur content decrease. The increase in nitrogen content may be because the nitrogen in the oil is contained in aromatic molecules which are thermodynamically more stable and therefore resistant to thermal cracking [21, 27, 28]. Similar results were also reported by some researchers $[4,10]$, who suggested that this may result from enhanced cracking reactions of kerogen leading to aromatics and polar compounds in the obtained oil. Moreover, the decrease in oxygen and sulfur contents is possibly because more oxygen and sulfur transform to gases or shale char.

Compared to three crude oils produced in China (Daqing, Shengli, and Xinjiang) [29], the atomic $\mathrm{H} / \mathrm{C}$ ratio of the derived shale oil is close to that of crude oils. However, nitrogen, oxygen and sulfur contents are higher. Moreover, the shale oil generated by retorting Dachengzi oil shale is classified as sweet and high-nitrogen crude oil in terms of the classification method of crude oil [30].

\subsubsection{High temperature simulated distillation}

Figure 4 compares the boiling point distributions of the recovered shale oils in 6, 20, 40 and $60 \mathrm{~min}$. The final boiling point (FBP) of shale oil samples is

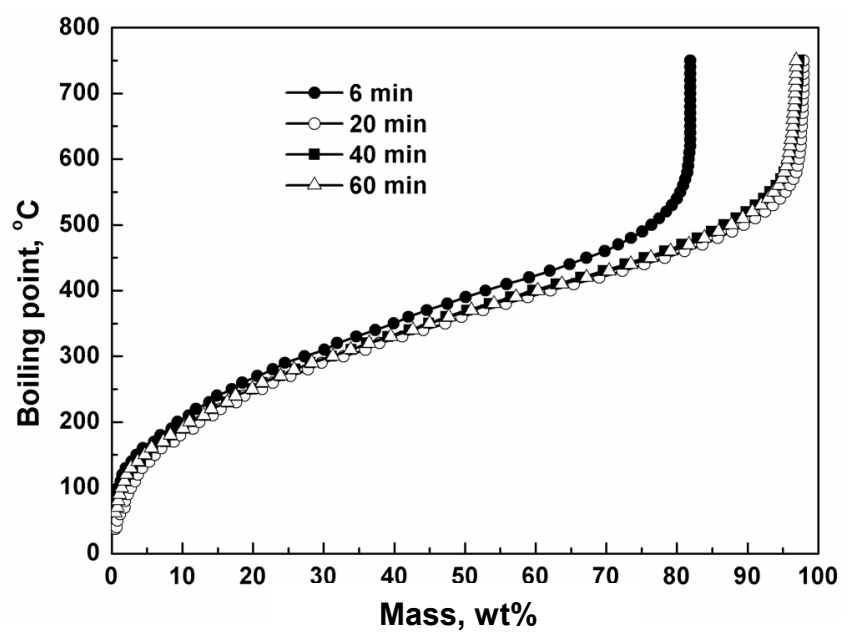

Fig. 4. Boiling point distributions of shale oils derived during different residence times. 
$750{ }^{\circ} \mathrm{C}$. It is noticeable that the boiling point of the shale oil produced during the residence time of $20 \mathrm{~min}$ is lowest and similar boiling point distributions appear for the shale oils obtained in 40 and $60 \mathrm{~min}$. In addition, the shale oil derived after 6 min contains a minimum amount of low boiling point oil. As the residence time increases, the content of low boiling point oil increases.

Table 2 further indicates that shale oils have fractions with a wide range of boiling points, mainly 9.3-12.4 wt\% light naphtha (IBP ab $200{ }^{\circ} \mathrm{C}$ ), $30.6-34.8 \mathrm{wt} \%$ medium fractions that can be used as diesel oil $\left(200-350{ }^{\circ} \mathrm{C}\right)$ [31], and 52.8-60.1 wt\% heavy fractions $\left(>350^{\circ} \mathrm{C}\right)$. As Table 2 shows, the shale oil produced in $6 \mathrm{~min}$ has the highest content of heavy fraction, $60.1 \mathrm{wt} \%$. At the same time, the shale oil obtained in $20 \mathrm{~min}$ has a minimum content of heavy fraction, $52.8 \mathrm{wt} \%$, and the highest total content of light naphtha and medium fraction, $47.2 \mathrm{wt} \%$. In addition, it is observed that the shale oils recovered in 40 and $60 \mathrm{~min}$ have a similar fractions distribution. The contents of light naphtha, medium fraction and heavy fraction of the shale oil derived in $40 \mathrm{~min}$ are $11.1 \mathrm{wt} \%, 33.8 \mathrm{wt} \%$ and $55.1 \mathrm{wt} \%$, respectively, being in the shale oil obtained in $60 \mathrm{~min} 11 \mathrm{wt} \%, 34 \mathrm{wt} \%$ and $55 \mathrm{wt} \%$, respectively. It is because of the complex nature of decomposition of kerogen as a complex heterogeneous mixture of organic compounds [32-34]. The kerogen in oil shale first breaks down into benzene soluble bitumen, and then the bitumen cracks thermally into oil, water and gases in the heating process. In the initial stage of retorting, the content of heavy oil fractions is high possibly because heavy oil fractions are stripped together with rapidlyproduced oil vapor and undergo pyrolysis to a limited extent [3]. Increasing the residence time improves the heat exchanges and the transfers of heat in kerogen during the pyrolysis process. So, prolonging the residence time affords the pyrolysis process of oil shale enough time to proceed. As the retorting progresses, the amount of high boiling point oils produced is

Table 2. Distillate fractions for shale oils derived by retorting Dachengzi oil shale and crude oils produced in China, wt\% of oil

\begin{tabular}{|l|c|c|c|c|}
\hline Oil fraction & $\begin{array}{c}\text { Oil } \\
\text { samples }\end{array}$ & $\begin{array}{c}\text { Light fraction } \\
\left(\mathrm{IBP} \sim 200^{\circ} \mathrm{C}\right)\end{array}$ & $\begin{array}{c}\text { Medium } \\
\text { fraction } \\
\left(200-350^{\circ} \mathrm{C}\right)\end{array}$ & $\begin{array}{c}\text { Heavy } \\
\text { fraction } \\
\left(>350^{\circ} \mathrm{C}\right)\end{array}$ \\
\hline Shale oil & $6 \mathrm{~min}$ & 9.3 & 30.6 & 60.1 \\
& $20 \mathrm{~min}$ & 12.4 & 34.8 & 52.8 \\
& $40 \mathrm{~min}$ & 11.1 & 33.8 & 55.1 \\
& $60 \mathrm{~min}$ & 11 & 34 & 55 \\
\hline Crude oils produced in China & Daqing $^{\mathrm{c}}$ & 11.5 & 19.7 & 68.8 \\
& Shengli $^{\mathrm{d}}$ & 7.6 & 17.5 & 74.9 \\
& Xinjiang $^{\mathrm{e}}$ & 15.4 & 26 & 59.6 \\
\hline
\end{tabular}

${ }^{\mathrm{c}}$ Daqing crude oil is obtained from Daqing oil field located in Daqing city, Heilongjiang province, China.

d Shengli crude oil is obtained from Shengli oil field located in Shandong province, China.

${ }^{\mathrm{e}}$ Xinjiang crude oil is obtained from Xinjiang oil field located in Xinjiang Uygur Autonomous Region, China. 
higher, whilst oil vapor and kerogen can be gradually pyrolyzed to become low boiling point oils [3]. For the overall recovered oil, the shale oil derived during the residence time of $20 \mathrm{~min}$ has the lowest boiling point.

Figure 5 shows the distillate fractions at intervals of $30{ }^{\circ} \mathrm{C}$ of the shale oils produced at different residence times. The light naphtha fractions (IBP ab $200^{\circ} \mathrm{C}$ ) and medium fractions $\left(200-350^{\circ} \mathrm{C}\right)$ have a similar boiling point distribution. The mean values of boiling points of the light naphtha fractions of shale oils produced in $6,20,40$ and $60 \mathrm{~min}$ are $127.2{ }^{\circ} \mathrm{C}, 94.5{ }^{\circ} \mathrm{C}$, $114.5^{\circ} \mathrm{C}$ and $121.7{ }^{\circ} \mathrm{C}$, respectively, while the respective values for the medium fractions are $242.5{ }^{\circ} \mathrm{C}, 242.2{ }^{\circ} \mathrm{C}, 241.5^{\circ} \mathrm{C}$ and $241.3{ }^{\circ} \mathrm{C}$. This distribution favors the cut of the shale oil as the naphtha and diesel oil in potential applications [31].

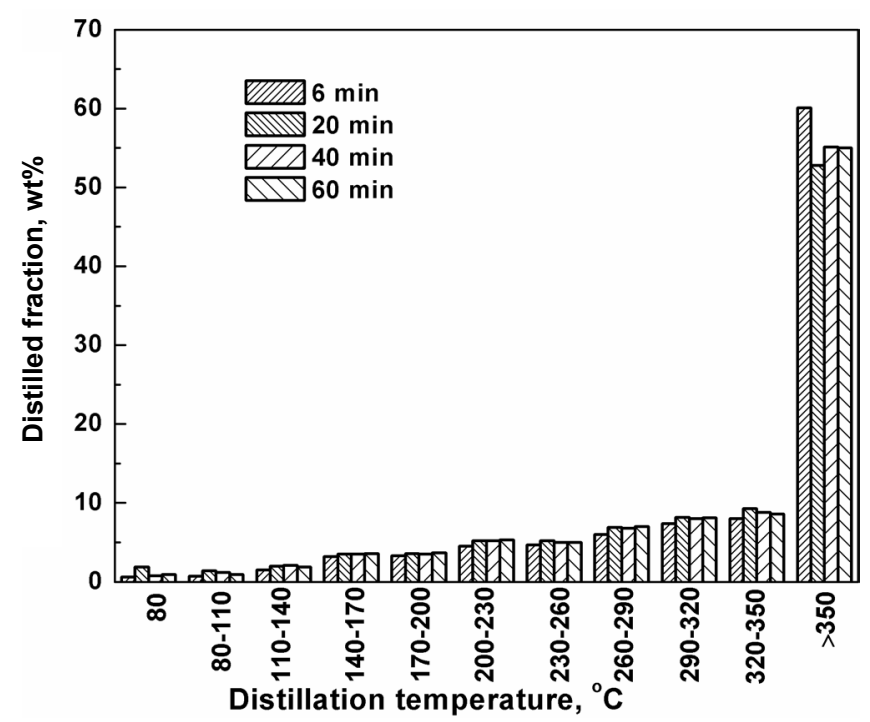

Fig. 5. Distillate fractions at intervals of $30{ }^{\circ} \mathrm{C}$ for shale oils obtained during different residence times.

In addition, Table 2 also compares the distillate fractions of the shale oil and three crude oils in China (Daqing, Shengli, and Xinjiang) [29]. The crude oil has a $59.6-74.9 \mathrm{wt} \%$ heavy fraction $\left(>350^{\circ} \mathrm{C}\right)$, while the shale oil only contains a $52.8-60.1 \mathrm{wt} \%$ heavy fraction. The shale oil is much lighter than the crude oil.

\subsubsection{Chemical class fractionation}

Figure 6 presents the weight percent of chemical class fractionation of the derived oil as a function of residence time. It is found that the aromatics content of the obtained shale oils increases from $10.71 \mathrm{wt} \%$ to $16.31 \mathrm{wt} \%$ 


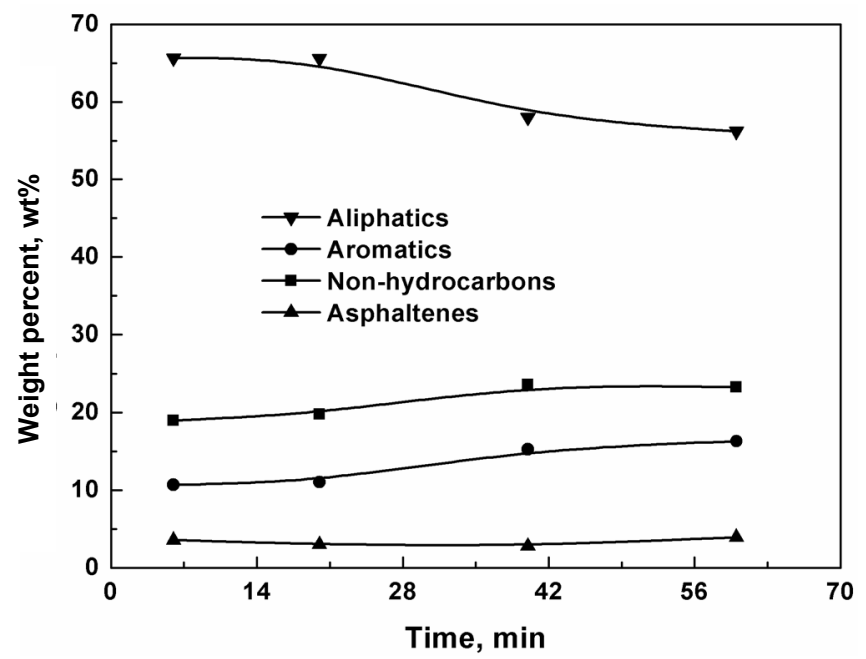

Fig. 6. Weight percent of chemical class fractionation of shale oils produced during different residence times.

with prolonging the residence time from 6 to $60 \mathrm{~min}$, while the aliphatics content decreases from $65.64 \mathrm{wt} \%$ to $56.19 \mathrm{wt} \%$. The aromatics content increases by $0.32 \mathrm{wt} \%$ with increasing residence time from 6 to $20 \mathrm{~min}$, by $4.24 \mathrm{wt} \%$ from 20 to $40 \mathrm{~min}$, and by $1.79 \mathrm{wt} \%$ from 40 to $60 \mathrm{~min}$. Simultaneously, the aliphatics content decreases by $0.06 \mathrm{wt} \%$ from 6 to $20 \mathrm{~min}$, by $7.6 \mathrm{wt} \%$ from 20 to $40 \mathrm{~min}$, and by $1.79 \mathrm{wt} \%$ from 40 to $60 \mathrm{~min}$. The results show that changes in aromatics and aliphatics contents are the most significant as the residence time rises from 20 to $40 \mathrm{~min}$. In addition, the non-hydrocarbons content of the produced shale oils increases from $19.00 \mathrm{wt} \%$ to $23.61 \mathrm{wt} \%$ with increasing residence time from 6 to $40 \mathrm{~min}$, while the asphaltenes content decreases from $3.57 \mathrm{wt} \%$ to $2.78 \mathrm{wt} \%$. However, the opposite changes occur in the non-hydrocarbons and asphaltenes content after $40 \mathrm{~min}$. The relative decrease in aliphatics concentration and increase in aromatics concentration of the shale oils suggests aromatization of oils with increasing residence time. The formation of aromatic compounds via secondary reactions during pyrolysis has been attributed to either the gasphase cracking of aliphatic compounds [28], or to Diels-Alder type reactions resulting in the selective concentration of aromatic compounds [21, 27]. Burnham [28] has suggested that since aromatic compounds are thermodynamically more stable than aliphatic compounds and therefore more resistant to thermal cracking reactions, the gas-phase cracking reactions will selectively produce oils with an increased concentration of aromatic hydrocarbons.

In addition, Wallman et al. [34] proposed a reaction network of oil shale pyrolysis. The kerogen in oil shale first decomposes into a light hydrocarbon product and a heavy intermediate product (bitumen). Subsequently, the 
bitumen is subject to two competing processes: heavy oil production and intraparticle (liquid-phase) coking. The produced oil is also subject to thermal cracking in the vapor phase surrounding the particles. The rate constants for the disappearance of bitumen are an order of magnitude smaller than the kerogen decomposition rate constant. In this work, the pyrolysis process proceeds more completely during a longer residence time, which increases the yield of aliphatics, aromatics, asphaltenes and non-hydrocarbons. On the other hand, the bitumen production rate is higher than its decomposition rate. Longer time may increase the amount of unreacted bitumen. The bitumen may be separated into asphaltenes and maltenes. Maltenes are composed of saturated and aromatic compounds, as well as non-hydrocarbons which are soluble in $n$-heptane $[35,36]$. As the residence time increases, the asphaltenes and maltenes content increases, but that of aromatics, aliphatics and non-hydrocarbons decreases. In addition, the cleavage of the lateral alkyl chains of asphaltenes may take place during a longer residence time [15]. So, there is a transition time of $40 \mathrm{~min}$ for Dachengzi oil shale during which the quantity of asphaltenes is the lowest and that of non-hydrocarbons is the highest.

\subsection{Gases analysis}

Table 3 presents the composition of hydrocarbon gases in the produced gases as a function of residence time. The hydrocarbon gases are mainly $\mathrm{C}_{1}-\mathrm{C}_{4}$ alkanes (methane, ethane, propane and butane) and $\mathrm{C}_{2}-\mathrm{C}_{4}$ alkenes (ethene, propene and butene). It can be observed that the total content of hydrocarbon gases increases from $697.41 \mathrm{mg} / \mathrm{Nm}^{3}$ to $5747.72 \mathrm{mg} / \mathrm{Nm}^{3}$ as the residence time increases from 6 to $40 \mathrm{~min}$, but decreases to $2643.07 \mathrm{mg} / \mathrm{Nm}^{3}$ during the residence time of $60 \mathrm{~min}$. The same trends are found in $\mathrm{C}_{1}-\mathrm{C}_{4}$ alkanes and $\mathrm{C}_{2}-\mathrm{C}_{4}$ alkenes gases contents, excluding propane. Accordingly, the content of this aliphatics decreases as the residence time increases from 6 to $60 \mathrm{~min}$ and the asphaltenes content first decreases before $40 \mathrm{~min}$ and then increases after $40 \mathrm{~min}$ in the obtained shale oils. Table 3 also shows the ratios of ethene/ethane, propene/propane, butene/butane and total alkene/ alkane gases as a function of residence time. The ratio of alkene to alkane gases in the evolved pyrolysis gases has been used to determine reaction mechanisms and indicate pyrolysis conditions. Some investigators have suggested that the increase in ethene/ethane, propene/propane, butene/butane and alkene/alkane ratios reflects the increase in secondary cracking reactions $[12,21,27,37]$. Table 3 confirms that the alkene/alkane ratio increases with increasing residence time from 6 to $60 \mathrm{~min}$, which may be attributed to the increasing secondary cracking reactions during a longer residence time. However, the ratios of ethene/ethane, propene/propane and butene/butane have no conclusive trend. The ethene/ethane ratio first decreases as the residence time increases from 6 to $40 \mathrm{~min}$, and then increases from 40 to $60 \mathrm{~min}$. However, the opposite trend is found in the propene/propane and butene/butane ratios as a function of residence time. 
Table 3. Composition of hydrocarbon gases derived by retorting Dachengzi oil shale as a function of residence time, $\mathrm{mg} / \mathrm{Nm}^{3}$

\begin{tabular}{|l|c|c|c|c|}
\hline \multirow{2}{*}{ Hydrocarbon gases } & \multicolumn{4}{c|}{ Residence time, min } \\
\cline { 2 - 5 } & 6 & 20 & 40 & 60 \\
\hline Methane & 363.63 & 1090.20 & 1834.82 & 436.88 \\
Ethane & 88.55 & 662.30 & 1349.68 & 747.47 \\
Propane & 44.19 & 136.75 & 192.75 & 249.26 \\
Butane & 50.90 & 213.68 & 288.89 & 164.77 \\
Ethene & 29.76 & 150.45 & 165.52 & 96.00 \\
Propene & 73.25 & 238.88 & 797.79 & 428.97 \\
Butene & 47.12 & 275.28 & 1118.27 & 519.73 \\
Total alkanes $\left(\mathrm{C}_{1}-\mathrm{C}_{4}\right)$ & 547.27 & 2102.92 & 3666.14 & 1598.37 \\
Total alkenes & 150.14 & 664.61 & 2081.58 & 1044.70 \\
Total hydrocarbon gases & 697.41 & 2767.53 & 5747.72 & 2643.07 \\
Ethene/ethane & 0.34 & 0.23 & 0.12 & 0.13 \\
Propene/propane & 1.66 & 1.75 & 4.14 & 1.72 \\
Butene/butane & 0.93 & 1.29 & 3.87 & 3.15 \\
Alkenes/alkanes & 0.27 & 0.32 & 0.57 & 0.65 \\
\hline
\end{tabular}

\section{Conclusions}

The experimental results show that residence time has a significant influence on the products yield and characteristics of shale oil and gases. The following conclusions can be inferred:

(1) Increasing residence time is helpful for the complete decomposition of kerogen as it improves the heat exchange and the transfer of heat in kerogen during the pyrolysis process; however, longer residence time will increase the input heat. As a result, the residence time of $40 \mathrm{~min}$ is optimal at the low retorting temperature, $430{ }^{\circ} \mathrm{C}$, ensuring high shale oil yield and saving on process cost.

(2) Increasing the residence time decreases the atomic $\mathrm{H} / \mathrm{C}$ ratio and sulfur and oxygen contents and increases nitrogen content in the recovered shale oil. This decrease of the atomic $\mathrm{H} / \mathrm{C}$ ratio has been suggested to be an indication of more aromatic oil production and the slight decrease in the atomic $\mathrm{H} / \mathrm{C}$ ratio after $40 \mathrm{~min}$ indicates that the characteristics of the shale oil after 40 min change only a little. The increase of the nitrogen content is possibly because the nitrogen in the shale char or gases participates in the aromatization process to form nitro-polycyclic aromatic hydrocarbons (NPAHs). Moreover, longer residence time enables more oxygen and sulfur to transform to gases or shale char.

(3) The atomic $\mathrm{H} / \mathrm{C}$ ratio in the derived shale oil is close to that in crude oils, and nitrogen, oxygen and sulfur contents are higher. The shale oil derived from Dachengzi oil shale by retorting is characterized as sweet and high-nitrogen crude oil in terms of the classification method of crude oil.

(4) In the initial stage of retorting, high amounts of heavy oil fractions are usually produced. Increasing residence time affords the pyrolysis process of 
oil shale enough time to proceed. Based on the above results, the shale oil obtained during the residence time of $20 \mathrm{~min}$ has the lowest quantity of heavy fractions. The shale oils obtained in 40 and $60 \mathrm{~min}$ show similar boiling point distributions. Moreover, the shale oil contains less heavy fractions than crude oil.

(5) Increasing the residence time from 6 to 60 min causes the increase in the aromatics content but the decrease in the aliphatics content because of the aromatization of the produced shale oils. In addition, the asphaltenes content first decreases from 6 to $40 \mathrm{~min}$ and then slightly increases from 40 to $60 \mathrm{~min}$, while the opposite trend holds true for the non-hydrocarbons content. There is a transition time of $40 \mathrm{~min}$ for Dachengzi oil shales during which the quantity of asphaltenes is the lowest and that of non-hydrocarbons is the highest because prolonging the residence time enables the complete pyrolysis of kerogen; however, the cleavage of the lateral alkyl chains of asphaltenes may take place during a longer residence time.

(6) As the residence time increases, nearly all $\mathrm{C}_{1}-\mathrm{C}_{4}$ alkanes and $\mathrm{C}_{2}-\mathrm{C}_{4}$ alkenes gases contents increase as the residence time increases from 6 min to $40 \mathrm{~min}$, and then decrease as the residence time increases from $40 \mathrm{~min}$ to $60 \mathrm{~min}$. In addition, the alkene/alkane ratio increases with increasing residence time, which reflects the increasing secondary cracking reactions during a longer residence time. The residence time of $40 \mathrm{~min}$ is a transition time with the lowest ethene/ethane ratio and the highest propene/propane and butene/butane ratios.

\section{Acknowledgement}

The authors express their gratitude to the State Key Laboratory of Heavy Oil Processing of China University of Petroleum for shale oil samples analysis and technical advice. This work was supported by the National Natural Science Foundation of China (Grant No. 50906051).

\section{REFERENCES}

1. BP Group. BP Statistical Review of World Energy June 2011 [R/OL]. http://www.bp.com/assets/bp_internet/globalbp/globalbp_uk_english/reports_an d_publications/statistical_energy_review_2011/STAGING/local_assets/pdf/stati stical_review_of_world_energy_full_report_2011.pdf.

2. IEA. World Energy Outlook $201 \overline{0}$ Executive Summary. http:// www.worldenergyoutlook.org/ docs/weo2010/weo2010_es_english.pdf.

3. Na, J. G., Im, C. H., Chung, S. H., Lee, K. B. Effect of oil shale retorting temperature on shale oil yield and properties. Fuel, 2012, 95, 131-135.

4. El harfi, K., Mokhlisse, A., Ben Chanâa, M. Yields and composition of oil obtained by isothermal pyrolysis of the Moroccan (Tarfaya) oil shales with steam or nitrogen as carrier gas. J. Anal. Appl. Pyrol., 2000, 56(2), 207-218. 
5. Dyni, J. R. Geology and resources of some world oil-shale deposits. Oil Shale, 2003, 20(3), 193-252.

6. Bauman, J. H., Deo, M. Simulation of a conceptualized combined pyrolysis, in situ combustion, and $\mathrm{CO}_{2}$ storage strategy for fuel production from Green River oil shale. Energ. Fuel., 2012, 26(3), 1731-1739.

7. Jaber, J. O., Probert, S. D. Non-isothermal thermogravimetry and decomposition kinetics of two Jordanian oil shales under different processing conditions. Fuel Process. Technol., 2000, 63(1), 57-70.

8. Al-Ayed, O. S., Matouq, M., Anbar, Z., Khaleel, A. M., Abu-Nameh, E. Oil shale pyrolysis kinetics and variable activation energy principle. Appl. Energ., 2010, 87(4), 1269-1272.

9. Dung, N. V. Factors affecting product yields and oil quality during retorting of Stuart oil shale with recycled shale: a screening study. Fuel, 1995, 74(4), 623627.

10. Dung, N. V. Yields and chemical characteristics of products from fluidized bed steam retorting of Condor and Stuart oil shales: effect of pyrolysis temperature. Fuel, 1990, 69(3), 368-376.

11. Solomon, P. R., Carangelo, R. M., Horn E. Effects of pyrolysis conditions on Israeli oil shale properties. Fuel, 1986, 65(5), 650-662.

12. Williams, P. T., Ahmad, N. Influence of process conditions on the pyrolysis of Pakistani oil shales. Fuel, 1999, 78(6), 653-662.

13. Han, X. X., Jiang, X. M., Cui, Z. G. Studies of the effect of retorting factors on the yield of shale oil for a new comprehensive utilization technology of oil shale. Appl. Energ., 2009, 86(11), 2381-2385.

14. Han, X. X., Jiang, X. M., Cui, Z. G., Liu, J. G., Yan, J. W. Effects of retorting factors on combustion properties of shale char. 3. Distribution of residual organic matters. J. Hazard. Mater., 2010, 175(1-3), 445-451.

15. Al-Harahsheh, A., Al-Ayed, O., Al-Harahsheh, M., Abu-El-Halawah, R. Heating rate effect on fractional yield and composition of oil retorted from El-lajjun oil shale. J. Anal. Appl. Pyrol., 2010, 89(2), 239-243.

16. Jaber, J. O., Probert, S. D., Williams, P. T. Evaluation of oil yield from Jordanian oil shales. Energy, 1999, 24(9), 761-781.

17. Nazzal, J. M. The influence of grain size on the products yield and shale oil composition from the Pyrolysis of Sultani oil shale. Energ. Convers. Manage., 2008, 49(11), 3278-3286.

18. Hurst, H. J., Levy, J. H., Patterson, J. H. Siderite decomposition in retorting atmospheres. Fuel, 1993, 72(6), 885-890.

19. Charlesworth, J. M. Oil shale pyrolysis. 1. Time and temperature dependence of product composition. Ind. Eng. Chem. Proc. Des. Dev., 1985, 24(4), $1117-$ 1125.

20. Salhi, N., Bennouna, C., Bitar, H., Sergent, M., Luu, R. P. T. An experimental design to optimize pyrolysis conditions of Timahdit (Morocco) oil shale. Fuel, 1996, 75(5), 633-640.

21. Williams, P. T., Nazzal, J. M. Polycyclic aromatic compounds in oils derived from the fluidised bed pyrolysis of oil shale. J. Anal. Appl. Pyrol., 1995, 35(2), 181-197.

22. Fassinou, W. F., Van De Steene, L., Toure, S., Volle, G., Girard, P. Pyrolysis of Pinus pinaster in a two-stage gasifier: Influence of processing parameters and thermal cracking of tar. Fuel Process. Technol., 2009, 90(1), 75-90. 
23. Abnisa, F., Wan Daud, W. M. A., Husin, W. N. W., Sahu, J. N. Utilization possibilities of palm shell as a source of biomass energy in Malaysia by producing bio-oil in pyrolysis process. Biomass Bioenerg., 2011, 35(5), 18631872.

24. López, A., De Marco, I., Caballero, B. M., Laresgoiti, M. F., Adrados, A. Influence of time and temperature on pyrolysis of plastic wastes in a semi-batch reactor. Chem. Eng. J., 2011, 173(1), 62-71.

25. Nazzal, J. M. Influence of heating rate on the pyrolysis of Jordan oil shale. J. Anal. Appl. Pyrol., 2002, 62(2), 225-238.

26. Nazzal, J. M. The presence of polycyclic aromatic hydrocarbons (PAH) in oil obtained at pyrolysis of Jordan oil shale. Oil Shale, 2007, 24(3), 465-475.

27. Williams, P. T., Nazzal, J. M. Polycyclic aromatic compounds in shale oils: influence of process conditions. Environ. Technol., 1998, 19(8), 775-787.

28. Burnham, A. K. Chemistry of shale oil cracking. In Oil Shale, Tar Sands, and Related Materials (Stauffer, H. C., ed.). American Chemical Society Symposium Series, 1981, 163(Chap. 4), 39-60.

29. Lin, S. X. Petroleum Refining Engineering (Third Edition). Petroleum Industry Press, Beijing, 2000 (in Chinese).

30. Sun, Z. L. Evaluation and Analysis of Crude Oils. China Petrochemical Press, Beijing, 2005 (in Chinese).

31. Li, S. Q., Yao, Q., Chi, Y., Yan, J. H., Cen, K. F. Pilot-scale pyrolysis of scrap tires in a continuous rotary kiln reactor. Ind. Eng. Chem. Res., 2004, 43(17), 5133-5145.

32. Williams, P. F. V. Thermogravimetry and decomposition kinetics of British Kimmeridge Clay oil shale. Fuel, 1985, 64(4), 540-545.

33. Torrente, M. C., Galán, M. A. Kinetics of the thermal decomposition of oil shale from Puertollano (Spain). Fuel, 2001, 80(3), 327-334.

34. Wallman, P. H., Tamm, P. W., Spars, B. G. Oil shale retorting kinetics. In Oil Shale, Tar Sand, and Related Materials (Stauffer, H. C., ed.). American Chemical Society Symposium Series, 1981, 163(Chap. 7), 93-113.

35. Trejo, F., Ancheyta, J., Centeno, G., Marroquín, G. Effect of hydrotreating conditions on Maya asphaltenes composition and structural parameters. Catal. Today, 2005, 109(1-4), 178-184.

36. Ancheyta, J., Centeno, G., Trejo, F., Marroquín, G. Changes in asphaltene properties during hydrotreating of heavy crudes. Energy Fuels, 2003, 17(5), 1233-1238.

37. Carter, S. D., Taulbee, D. N. Fluidized bed steam retorting of Kentucky oil shale. Fuel Process. Technol., 1985, 11(3), 251-272.

Presented by E. Volkov

Received December 3, 2012 